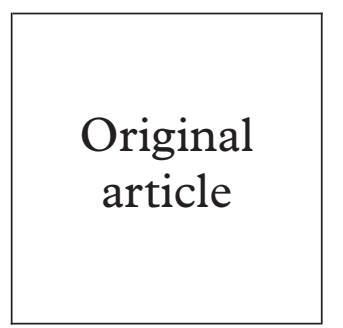

\title{
Acute pulmonary embolism in patients with HIV disease
}

\author{
Sarah J Howling, Penny J Shaw, Robert F Miller
}

Objectives: To determine the incidence, mode of presentation, and outcome of pulmonary embolism (PE) in patients with HIV infection.

Methods: Retrospective review of clinical case records, imaging department database, and necropsy reports of patients admitted to the specialist HIV/AIDS unit at UCL hospitals from April 1993 to August 1997 in order to identify those with a diagnosis of PE.

Results: During the study period there were 3792 admissions of whom $10(0.26 \%)$ had PE. All patients with PE presented with fever, seven were dyspnoeic, and seven had cough: all were thought initially to have respiratory infection. Only five patients had pleural pain. All 10 patients had abnormal baseline chest radiographs. The diagnosis in six was made by computed tomograph (CT) pulmonary angiography, in two was made by ventilation perfusion $(\mathrm{V} / \mathrm{Q})$ scanning, in one by both techniques, and in one at necropsy. CT angiography in addition to identifying thrombus also showed concomitant lung parenchymal abnormalities in all but one patient. Nine patients with PE had one or more risk factors for venous thromboembolism as did 34/40 case matched controls (odds ratio $=1.67 ; 95 \%$ confidence interval $=0.18-15.5$ ). All patients diagnosed in life were anticoagulated and five survived.

Conclusions: PE was uncommon in this HIV infected population. The diagnosis should be considered in patients with respiratory infection which does not respond to antibiotics. Identifiable risk factors for venous thromboembolism appear to be unhelpful in increasing clinical index of suspicion for PE. As baseline chest radiographs are frequently abnormal, the diagnostic utility of $\mathrm{V} / \mathrm{Q}$ scanning may be reduced and CT pulmonary angiography is the imaging modality of first choice.

(Sex Transm Inf 1999;75:25-29)

Keywords: pulmonary embolism; V/Q scan; angiography; HIV; AIDS

\section{Introduction}

Acute pulmonary embolism is a common but potentially fatal condition that is frequently overlooked in life. In the general population, pulmonary emboli are directly responsible for $10 \%$ of all deaths in hospital and contribute to a further $10 \% .{ }^{1}$ Several major risk factors for venous thromboembolism have been identified including recent abdominal surgery, disseminated malignancy, previous venous thromboembolism, immobilisation for more than 1 week, disabling cardiorespiratory disease, age $>40$ years, and thrombotic disorders. ${ }^{2-5}$ In contrast, reports of pulmonary embolism in HIV infected individuals are scarce, despite descriptions of the hypercoagulable state due to HIV associated lupus anticoagulant, anticardiolipin antibodies, and protein $\mathrm{S}$ deficiency. ${ }^{6}$

Diagnosis of acute pulmonary embolism may be difficult and usually relies on a strong clinical history with supportive imaging, most often a ventilation/perfusion (V/Q) scan. This imaging strategy was recently reassessed by the British Thoracic Society who reaffirmed the position of $\mathrm{V} / \mathrm{Q}$ scanning in the diagnostic algorithm. ${ }^{2}$ However, investigation is thwarted by a reduced index of suspicion and by the reduced utility of $\mathrm{V} / \mathrm{Q}$ scanning in patients who have abnormal chest radiographs. ${ }^{57}$

This study describes the mode of presentation, major risk factors, method of diagnosis, and outcome of acute pulmonary embolism in a series of HIV infected patients. These cases illustrate the difficulties encountered in diagnosing pulmonary embolism in this patient population, who frequently have multiple pathologies and emphasises the diagnostic utility of spiral computed tomograph (CT) pulmonary angiography if there is clinical suspicion of pulmonary thromboembolic disease.

\section{Methods}

For the period 1 April 1993 to 1 September 1997 we retrospectively reviewed (a) the discharge summaries, patient records, and necropsy reports of all patients admitted to the specialist HIV/AIDS unit at University College London (UCL) hospitals and searched manually and electronically for the words "pulmonary embolus/embolism", (b) the records of the imaging department and the Institute of Nuclear Medicine, UCL hospitals, in order to identify those HIV infected patients who underwent CT pulmonary angiography and V/Q scanning, and (c) the hospital PAS system in order to identify the number of admissions to the HIV/AIDS unit. We also noted the total number of patients admitted to the HIV/AIDS unit over this period with respiratory problems and the number who underwent bronchoscopy. Finally, we noted all the recorded deaths in HIV positive patients.

From the case records of each patient with pulmonary embolism details of age, sex, ethnicity, risk factors for HIV infection, CD4 lymphocyte count, major risk factors for 
venous thromboembolism, mode of presentation, results of investigations, including $\mathrm{V} / \mathrm{Q}$ scanning and CT angiography, and of necropsy (if performed) were obtained. For each patient with pulmonary embolism we identified four case matched patients by identifying the two patients admitted to the HIV/AIDS inpatient unit with respiratory problems immediately before and after the index case. In these case matched patients we sought evidence, by case note review, of the presence of major risk factors for venous thromboembolism. ${ }^{2-5}$ The presence of risk factors for thromboembolism was compared in HIV infected patients with and without pulmonary embolism by means of an odds ratio using a Mantel-Haenszel estimate.

\section{Results}

Ten patients with pulmonary embolism were identified. All were male and were aged 33-57 years (median 37 years). Of the patients nine were white homosexuals and one was an Indian heterosexual. As a group they were profoundly immunosuppressed with median CD 4 count of 45 cells $\times 10^{6} / 1$ (range $10-240$, normal range $350-2200$ cells $\left.\times 10^{6} / 1\right)$. Six patients had no prior AIDS defining episodes, three had prior Pneumocystis carinii pneumonia (one also had cytomegalovirus retinitis), and one had

Table 1 Risk factors, clinical presentation, results of imaging, treatment, and outcome from pulmonary embolism

\begin{tabular}{|c|c|c|c|c|c|c|}
\hline \multirow[b]{2}{*}{$\begin{array}{l}\text { Patient } \\
\text { No }\end{array}$} & \multirow[b]{2}{*}{$\begin{array}{l}\text { Major risk factors for } \\
\text { pulmonary embolism }\end{array}$} & \multirow[b]{2}{*}{$\begin{array}{l}\text { Clinical } \\
\text { presentation }\end{array}$} & \multicolumn{3}{|l|}{ Imaging } & \multirow[b]{2}{*}{ Treatment and outcome } \\
\hline & & & $\begin{array}{l}\text { Chest } \\
\text { radiograph }\end{array}$ & $V / Q \operatorname{scan}$ & $\begin{array}{l}\text { CT pulmonary } \\
\text { angiography }\end{array}$ & \\
\hline 1 & $\begin{array}{l}\text { Previous femoral } \\
\text { DVT } \times 2 \text {, previous } \\
\text { PE, immobile }>1 \\
\text { week, severe } \\
\text { asthma/COAD, age } \\
>40 \text { years }\end{array}$ & $\begin{array}{l}\text { Fever, } \\
\text { breathlessness, } \\
\text { non-productive } \\
\text { cough }\end{array}$ & $\begin{array}{l}\text { Bilateral } \\
\text { patchy focal } \\
\text { areas of } \\
\text { consolidation }\end{array}$ & $\begin{array}{l}\text { Multiple perfusion } \\
\text { defects both lungs } \\
\text { with preserved } \\
\text { ventilation = high } \\
\text { probability scan }\end{array}$ & $\begin{array}{l}\text { Bilateral large main } \\
\text { pulmonary artery } \\
\text { PE, patchy lung } \\
\text { parenchymal } \\
\text { consolidation }\end{array}$ & $\begin{array}{l}\text { Anticoagulated, } \\
\text { survived }\end{array}$ \\
\hline 2 & $\begin{array}{l}\text { Previous popliteal } \\
\text { DVT, current } \\
\text { popliteal DVT, } \\
\text { immobile > } 1 \text { week, } \\
\text { severe chronic } \\
\text { asthma }\end{array}$ & $\begin{array}{l}\text { Fever, } \\
\text { breathlessness, } \\
\text { non-productive } \\
\text { cough, chest } \\
\text { pain }\end{array}$ & $\begin{array}{l}\text { Bilateral } \\
\text { diffuse } \\
\text { consolidation }\end{array}$ & $\begin{array}{l}\text { Multiple matched } \\
\text { and unmatched } \\
\text { perfusion defects = } \\
\text { indeterminate scan }\end{array}$ & $\begin{array}{l}\text { PE in right main } \\
\text { pulmonary artery, } \\
\text { both basal arteries } \\
\text { and multiple } \\
\text { segmental lower } \\
\text { lobe arteries, } \\
\text { bilateral pleural } \\
\text { effusions and patchy } \\
\text { consolidation }\end{array}$ & Anticoagulated, died \\
\hline 3 & None & $\begin{array}{l}\text { Fever, } \\
\text { breathlessness, } \\
\text { productive } \\
\text { cough, chest } \\
\text { pain }\end{array}$ & $\begin{array}{l}\text { Consolidation } \\
\text { in lingula and } \\
\text { right } \\
\text { costophrenic } \\
\text { angle }\end{array}$ & $\begin{array}{l}\text { Multiple bilateral } \\
\text { unmatched } \\
\text { perfusion defects = } \\
\text { high probability } \\
\text { scan }\end{array}$ & $\begin{array}{l}\text { No thrombus seen, } \\
\text { alveolar } \\
\text { consolidation in } \\
\text { lingula and posterior } \\
\text { segment of right } \\
\text { lower lobe }\end{array}$ & $\begin{array}{l}\text { Anticoagulated, } \\
\text { survived }\end{array}$ \\
\hline 4 & $\begin{array}{l}14 \text { days post } \\
\text { splenectomy }\end{array}$ & $\begin{array}{l}\text { Fever, chest } \\
\text { pain }\end{array}$ & $\begin{array}{l}\text { Small left } \\
\text { pleural } \\
\text { effusion }\end{array}$ & $\begin{array}{l}\text { Unmatched } \\
\text { perfusion defects at } \\
\text { left apex and base } \\
=\text { high probability } \\
\text { scan }\end{array}$ & Not done & $\begin{array}{l}\text { Anticoagulated, } \\
\text { survived }\end{array}$ \\
\hline 5 & $\begin{array}{l}\text { Disseminated } \\
\text { malignancy } \\
\text { (lymphoma), recent } \\
\text { major abdominal } \\
\text { surgery, immobile } \\
>1 \text { week }\end{array}$ & $\begin{array}{l}\text { Fever, } \\
\text { productive } \\
\text { cough, chest } \\
\text { pain }\end{array}$ & $\begin{array}{l}\text { Left basal } \\
\text { consolidation }\end{array}$ & Not done & $\begin{array}{l}\text { Large PE in both } \\
\text { pulmonary arteries }\end{array}$ & Anticoagulated, died \\
\hline 6 & Immobile $>1$ week & $\begin{array}{l}\text { Fever, } \\
\text { breathlessness, } \\
\text { productive } \\
\text { cough }\end{array}$ & $\begin{array}{l}\text { Diffuse } \\
\text { bilateral } \\
\text { airspace } \\
\text { shadowing }\end{array}$ & Not done & $\begin{array}{l}\text { PE in both basal } \\
\text { arteries, } \\
\text { consolidation right } \\
\text { lower lobe, } \\
\text { widespread ground } \\
\text { glass opacification }\end{array}$ & Anticoagulated, died \\
\hline 7 & $\begin{array}{l}\text { Previous right } \\
\text { femoral DVT, } \\
\text { current DVT, } \\
\text { immobile }>1 \text { week, } \\
\text { age }>40 \text { years }\end{array}$ & $\begin{array}{l}\text { Fever, } \\
\text { breathlessness }\end{array}$ & $\begin{array}{l}\text { Bilateral } \\
\text { lower lobe } \\
\text { consolidation }\end{array}$ & Not done & $\begin{array}{l}\text { Large bilateral PE in } \\
\text { basal arteries; } \\
\text { bilateral lower lobe } \\
\text { consolidation }\end{array}$ & Anticoagulated, died \\
\hline 8 & $\begin{array}{l}\text { Previous right } \\
\text { popliteal DVT, } \\
\text { immobile }>1 \text { week, } \\
\text { age }>40 \text { years }\end{array}$ & $\begin{array}{l}\text { Fever, } \\
\text { breathlessness, } \\
\text { productive } \\
\text { cough, chest } \\
\text { pain }\end{array}$ & $\begin{array}{l}\text { Patchy } \\
\text { bilateral } \\
\text { consolidation, } \\
\text { hyperinflated } \\
\text { lungs }\end{array}$ & Not done & $\begin{array}{l}\text { Multiple PE } \\
\text { bilaterally in upper } \\
\text { and lower lobes, } \\
\text { patchy lung } \\
\text { parenchymal } \\
\text { consolidation }\end{array}$ & $\begin{array}{l}\text { Anticoagulated, } \\
\text { survived }\end{array}$ \\
\hline 9 & $\begin{array}{l}\text { Immobile }>1 \text { week, } \\
\text { elevated IgM } \\
\text { cardiolipin } 7.0 \text { units } \\
\text { (normal range } 0-5 \\
\text { units) }\end{array}$ & $\begin{array}{l}\text { Fever, } \\
\text { haemophysis, } \\
\text { productive } \\
\text { cough, chest } \\
\text { pain }\end{array}$ & $\begin{array}{l}\text { Right basal } \\
\text { consolidation }\end{array}$ & Not done & $\begin{array}{l}\text { PE in right basal } \\
\text { pulmonary artery, } \\
\text { right basal lung } \\
\text { consolidation and } \\
\text { pleural effusion }\end{array}$ & $\begin{array}{l}\text { Anticoagulated, } \\
\text { survived }\end{array}$ \\
\hline 10 & $\begin{array}{l}\text { Immobile }>1 \text { week, } \\
\text { age }>40 \text { years, } \\
\text { varicose veins }\end{array}$ & $\begin{array}{l}\text { Fever, } \\
\text { breathlessness, } \\
\text { non-productive } \\
\text { cough }\end{array}$ & $\begin{array}{l}\text { Bilateral } \\
\text { diffuse } \\
\text { consolidation }\end{array}$ & Not done & Not done & $\begin{array}{l}\text { No treatment, died. } \\
\text { Necropsy showed } P \\
\text { carinii and CMV } \\
\text { pneumonitis and } \\
\text { embolus in both } \\
\text { main pulmonary } \\
\text { arteries }\end{array}$ \\
\hline
\end{tabular}


Kaposi's sarcoma. All 10 patients had presented with respiratory symptoms which had initially been ascribed to infection but had failed to respond to antibiotics (table 1). All patients had abnormal baseline chest radiographs (table 1).

The diagnosis of pulmonary embolism was made by $\mathrm{V} / \mathrm{Q}$ scanning in two patients. In six further patients the diagnosis was made by CT pulmonary angiography, in one patient the diagnosis was made by both techniques, and in the final patient the diagnosis was made at necropsy. In one patient (No 2, table 1) the $\mathrm{V} / \mathrm{Q}$ scan was indeterminate for pulmonary embolism showing multiple matched and unmatched perfusion defects, and the CT angiogram showed multiple pulmonary emboli (fig 1). In another patient (No 3, table 1) the V/Q scan was abnormal, showing multiple unmatched perfusion defects. The patient was anticoagulated with intravenous heparin and a CT pulmonary angiogram was carried out 4 days later. This showed no emboli. All eight patients who underwent CT pulmonary angiography also had thin collimation $(2 \mathrm{~mm})$ scans before the contrast study. These revealed additional lung parenchymal abnormalities in seven patients (fig 2, table 1 ).

During the study period 1255 patients had a total of 3792 admission to the HIV/AIDS unit. Of these, 513 patients had 566 admissions with respiratory episodes (including the 10 with pulmonary embolism). Four hundred and eighty one patients underwent fibreoptic bronchoscopy. Only two had evidence of cytomegalovirus infection in bronchoalveolar lavage
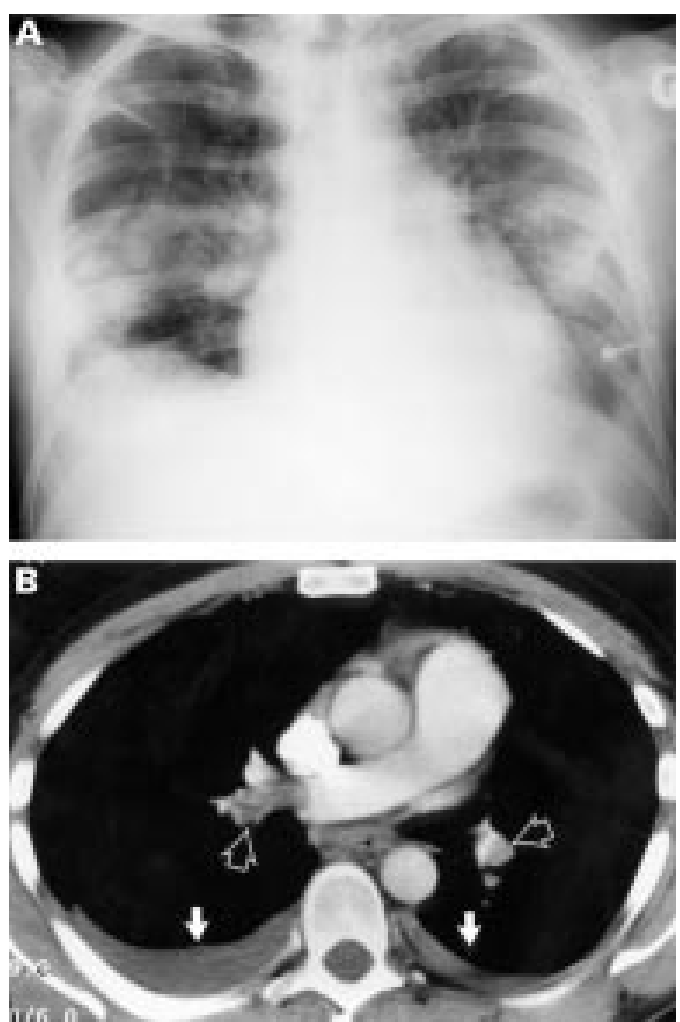

Figure 1 (Patient No 2) (A) Chest radiograph showing bilateral, multifocal consolidation and a right basal pleural effusion. (B) The spiral CT pulmonary angiogram reveals bilateral pleural effusions (arrows) and large filling defects, due to emboli in the right main and left basal pulmonary arteries (open arrows). fluid. Thus, pulmonary embolism accounted for $0.26 \%$ of all admissions and $1.76 \%$ of admissions with acute respiratory episodes.

An additional $14 \mathrm{HIV}$ positive patients underwent $\mathrm{V} / \mathrm{Q}$ scanning and a further 14 underwent CT pulmonary angiography during the study period. In these 28 patients imaging gave negative results for pulmonary embolism and alternative diagnoses were made. In all, 363 deaths in HIV positive patients were recorded during the study period. Of these, 167 patients died in hospital and 196 died at home or in a hospice. Sixty eight necropsies were performed of which 65 were on patients dying in hospital and three were on patients who died at home or in a hospice. There was evidence of pulmonary embolism in only one patient (No 10, table 1). The overall necropsy
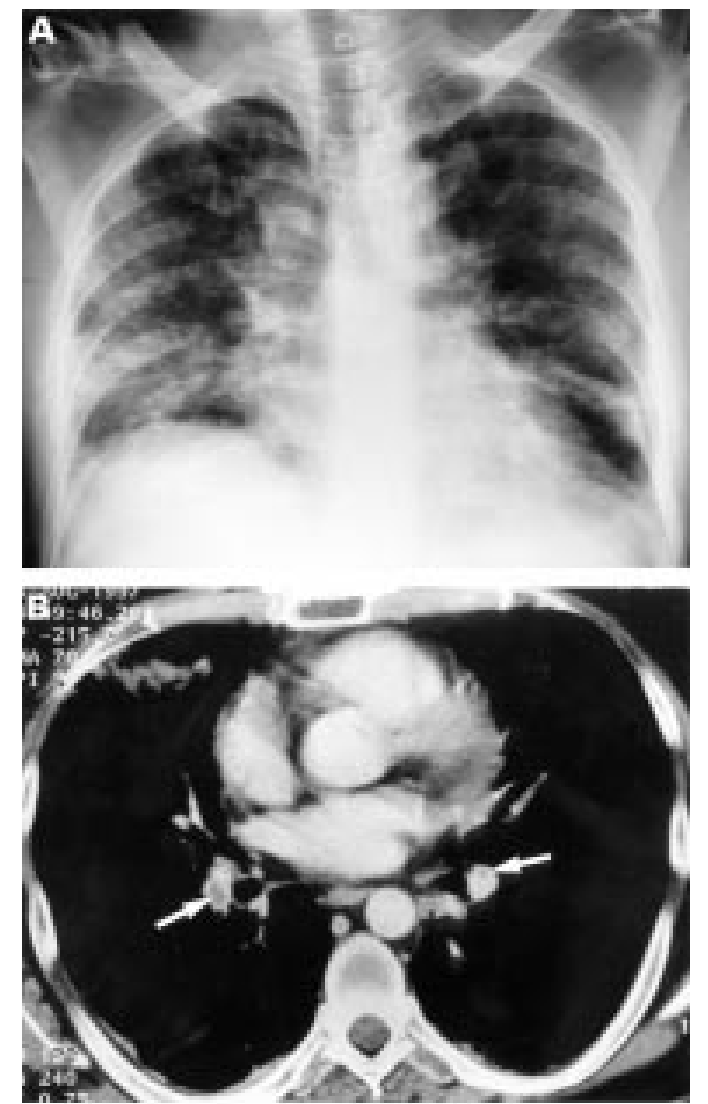

c

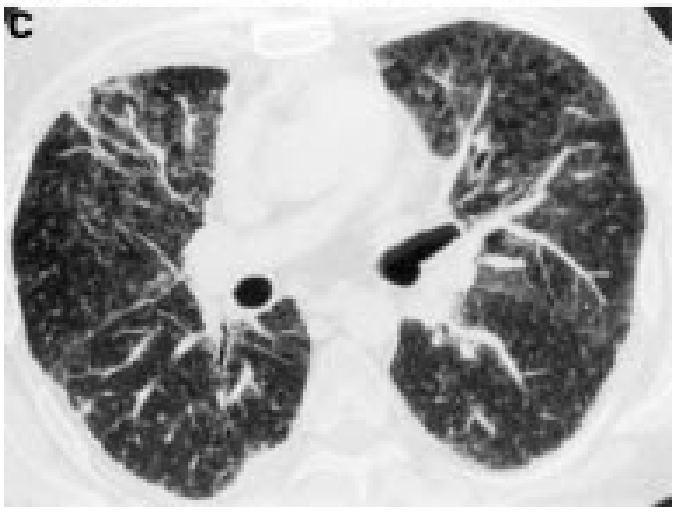

Figure 2 (Patient No 6) (A) Chest radiograph showing diffuse, bilateral airspace shadowing, (B) spiral CT pulmonary angiogram revealing pulmonary emboli (arrows) within the opacified pulmonary arteries on mediastinal windows, and (C) CT scan showing a bilateral, hazy, ground glass pattern of increased lung attenuation on lung windows. 
rate was $18.7 \%(68 / 363)$ and the necropsy rate for in hospital deaths was 38.9\% (65/167).

All nine patients in whom pulmonary embolism was diagnosed in life were anticoagulated and five survived. As a group the HIV infected case matched controls were also profoundly immunosuppressed with a median CD4 count of 30 cells $\times 10^{6} / 1$ (range $0-480$ ). Major risk factors for venous thromboembolism were present in nine of the 10 patients with pulmonary embolism (table 1) and were present in 34 of the 40 case matched controls. Odds ratio (Mantel-Haenszel estimate) was $1.67 ; 95 \%$ confidence interval 0.18-15.5.

\section{Discussion}

This study sought to describe the incidence, mode of presentation, method of diagnosis, and outcome of pulmonary embolism in HIV infected patients admitted to a specialist unit. Of 3792 admissions, 10 patients $(0.26 \%)$ had pulmonary embolism, nine of whom were diagnosed antemortem. All had presented with respiratory symptoms which were ascribed initially to infection. However, failure to respond to antibiotic treatment in nine cases raised the possibility of pulmonary thromboembolic disease which was confirmed by CT pulmonary angiography in six, V/Q scanning in two, and both techniques in one patient. This permitted modification of anti-infective medication and commencement of anticoagulation. The majority of our patients with pulmonary embolism had major risk factors for venous thromboembolism as did most of the matched controls. This suggests that identification of major risk factors for venous thromboembolism may be unhelpful for increasing the clinical index of suspicion for pulmonary embolism in HIV infected patients presenting with respiratory symptoms.

A number of abnormalities of coagulation have been described in patients with HIV infection. ${ }^{6}$ The most common is caused by lupus anticoagulant which is found in up to $60 \%$ of patients and may be associated with major thromboembolic phenomena. ${ }^{9}$ Other coagulation abnormalities that occur in HIV infected patients include anticardiolipin antibodies and reduced levels of active protein $\mathrm{S} .{ }^{6}$ Several opportunistic infections, particularly cytomegalovirus and herpes simplex virus types 1 and 2, may contribute to the prothrombotic state by converting vascular endothelial cells from a non-coagulative to a procoagulative phenotype, leading to expression to procoagulant phospholipids. ${ }^{10}$ In this study cytomegalovirus was found in bronchoalveolar lavage fluid of only two of the 481 patients who underwent bronchoscopy and this pathogen was identified in the lungs at necropsy in only one patient (No 10) with pulmonary embolism. Although raised IgM cardiolipid antibody levels were found in one of our patients (No 9) we did not seek evidence of coagulation abnormalities in the other patients. It is possible that in addition to other major risk factors for venous thromboembolism, our patients may have had abnormalities of coagulation. Despite these many factors which result in a prothrom- botic state, reports of venous thromboembolic disease in HIV infected patients are sparse. In one study, Becker et al described three patients with prior AIDS defining illnesses who presented with pulmonary embolism. None had clinically major risk factors for venous thromboembolism. Coagulation studies showed one had a low protein S level and one had weakly positive anticardiolipin antibodies. ${ }^{11}$

Necropsy studies of the general population reveal that pulmonary embolism is not an infrequent cause of death, but one commonly underdiagnosed, with antemortem accuracy rates varying from $39 \%$ to $50 \% .^{12}{ }^{13}$ These data suggest that cases of pulmonary embolism may have been missed in our study. Necropsy in our study revealed only one case undiagnosed in life. However, we only obtained permission for necropsy in $18.7 \%$ of all deaths and $38.9 \%$ of all deaths in hospital. A retrospective study of 101 necropsies on HIV infected patients performed in two metropolitan hospitals in New York showed pulmonary embolism in seven patients $(6.9 \%)$. In four cases the diagnosis had been made in life and in three, the diagnosis was only revealed by necropsy. ${ }^{14}$ Of 50 consecutive necropsies on HIV infected patients at St Thomas's Hospital, London, a similar incidence has been reported with only one case of pulmonary embolism (S B Lucas, personal communication). In contrast, pulmonary embolism was identified in 40 of 233 necropsies $(17 \%)$ on HIV infected patients from Jacksonville, Florida and Washington DC, USA. All patients had major infective and/or malignant pulmonary pathology in addition to pulmonary embolism. In none of the cases did it appear that pulmonary embolism had a significant clinical impact on death. $^{15}$

In the search of suspected pulmonary emboli, basic imaging investigations may support clinical suspicion and exclude alternative diagnoses. Chest radiographic appearances may be relatively non-specific and often confusing. Common radiographic findings in pulmonary embolism, including focal consolidation, segmental collapse, elevation of the hemidiaphragm, and pleural effusion in patients with HIV disease, are more often due to infection and serial change in the chest radiograph is perhaps the most helpful feature. Moreover, the picture in HIV infected patients is often complicated as the majority of patients have a prior history of pulmonary disease and an abnormal baseline chest radiograph.

Conventional pulmonary arteriography remains the "gold standard" investigation for suspected pulmonary embolism; however, clinicians are reluctant to request it even when appropriate probably because it is invasive with a $2 \%$ risk of associated morbidity, difficult to organise (only 15\% of British radiology departments offer the service), and there is a general lack of expertise in interpretation. ${ }^{16}$ Currently in the United Kingdom V/Q scanning is the most frequently performed investigation for suspected pulmonary embolism and is recommended as a first line investigation by the British Thoracic Society. ${ }^{2}$ Unfortunately, many 
$\mathrm{V} / \mathrm{Q}$ scans are reported as being of low or intermediate (indeterminate) probability $(>60 \%$ of scans in some series) and are essentially non-diagnostic, since $12 \%-33 \%$ of these patients will have pulmonary embolism. ${ }^{17} 18$ Patients with an abnormal chest radiograph are most likely to have an indeterminate V/Q scan and require further imaging to allow a definitive diagnosis to be made. ${ }^{7}$ In contrast with the British Thoracic Society recommendations, a recent prospective study from Cambridge which compared CT pulmonary angiography with $\mathrm{V} / \mathrm{Q}$ scanning for diagnosis of pulmonary embolism in non-HIV infected patients, recommended that in patients with suspected pulmonary embolism and known cardiorespiratory abnormalities, CT pulmonary angiography should be the investigation of first choice because of the reduced utility of V/Q scintigraphy. ${ }^{19}$

Spiral CT pulmonary angiography is a minimally invasive technique that directly demonstrates pulmonary thrombus. It has a higher sensitivity and specificity than V/Q scintigraphy at $90 \%(75-100 \%)$ and $92 \%(76-100 \%)$, respectively. ${ }^{20-23} \mathrm{~A}$ further major advantage is that with this technique it is possible to evaluate the morphology of the mediastinum, bronchial tree, pleura, and lung parenchyma providing additional information and aiding in differential diagnosis. This is especially relevant in the population who are HIV infected in whom multiple pathologies are common. Despite the advantages of CT pulmonary angiography, this technique is unable to identify reliably emboli within subsegmental pulmonary arteries. ${ }^{2023-25}$ Reliable demonstration of emboli at the subsegmental level requires conventional pulmonary arteriography although recent advances in spiral CT pulmonary angiography may challenge this. The prevalence of isolated subsegmental clots is small, probably in the region of $6 \%,{ }^{18} 2225$ and they are unlikely to be the cause of a major episode unless they occur in a patient with limited cardiorespiratory reserve.

Pulmonary embolism was uncommon in this HIV infected population, accounting for $0.26 \%$ of all admissions. The diagnosis should be considered in HIV infected patients presenting with respiratory infection which does not respond to antibiotics. With anticoagulation over half of our patients survived. As baseline chest radiographs are frequently abnormal the diagnostic utility of $\mathrm{V} / \mathrm{Q}$ scanning is reduced and CT pulmonary angiography is the imaging modality of first choice. If results from this investigation are negative and clinical suspicion remains then conventional pulmonary arteriography should be considered.

We thank Dr Andrew Nunn, senior statistician, MRC HIV Clinical Trials Centre for statistical advice, Dr Peter Jarritt for obtaining nuclear medicine data, David Cornforth, Robert Kite, and Julie Dodds for patient data collection, and Louise Hinds and Julie Dodds for patient data collection, and Louise Hind Williams, and Ali Zumla for allowing us to report on their patients.
Contributors: All authors contributed to the design of the study, to data collection and analysis, and to writing drafts of the manuscript. Dr S Howling collated the imaging data and together with Dr P Shaw, summarised the findings and produced the images. Dr R Miller put forward the original research proposal.

1 Linblad B, Sternby WH, Berquist D. Incidence of venous thromboembolism verified by necropsy over 30 years. $B M \mathcal{F}$ 1991;302:709-11.

2 British Thoracic Society, Standards of Care Committee. Suspected acute pulmonary embolism: a practical approach. Thorax 1997;52 (Suppl 4):S3-24.

3 Donnamaria V, Palla A, Petruzzelli S, et al. A way to select on clinical ground patients with high risk for pulmonary embolism: a retrospective analysis in a nested case-control study. Respiration 1995;62:201-4.

4 Schroder HM, Andreassen M. Autopsy-verified major pulmonary embolism after hip fracture. Clin Orthop Rel Res 1993;293:196-203.

5 Anderson FA, Wheeler B, Goldberg RJ, et al. A populationbased perspective of the hospital incidence and case-fatality rates of deep vein thrombosis and pulmonary embolism. Arch Intern Med 1991;151:933-8.

6 DeVita V, Hellman S, Rosenberg SA, eds. Haematological complications of human immunodeficiency virus infection. In: AIDS aetiology, diagnosis, treatment and prevention. 4th ed. Philadelphia: Lippincott-Raven, Chapter 19.4:429-41.

7 Goldberg SN, Palmer EL, Scot JA, et al. Pulmonary embolism: prediction of the usefulness of initial ventilationperfusion scanning with chest radiographic findings. Radiology 1994;193:801-5.

8 Breslow NE, Day NE. The analysis of case-control studies. Statistical methods in cancer research. Vol 1. Lyons: Statistical methods in cancer research. Vol 1. Lyons: Internationa

9 Bloom EJ, Abrams DI, Rogers G. Lupus anticoagulant in the acquired immunodeficiency syndrome. $\mathscr{F} A M A$ 1986; 256:491-3.

10 Herstein L, Cappacino A. Platelet functional and bound antibodies in AIDS-ARC patients with thrombocytopenia (Abstract). Blood 1987;70:118a.

11 Becker DM, Saunders TJ, Wispelwey B, et al. Venous thromboembolism in AIDS. Am f Med Sci 1992;303:395-

12 Gross JS, Neufeld RR, Libow LS, et al. Autopsy study of the elderly institutionalised patient: review of 234 autopsies. Arch Intern Med 1998;148:173-6.

13 Rossman I, Rodstein M Bornstein A. Undiagnosed diseases in an ageing population. Arch Intern Med 1974;133:366-9.

14 Wilkes MS, Fortin AH, Felix JC, et al. Value of necropsy in the acquired immunodeficiency syndrome. Lancet 1988;ii: the acqu.

15 Afessa B, Green W, Chiao J, et al. Pulmonary complications of HIV infection. Autopsy findings. Chest 1998;133:1225-

16 Cooper TJ, Hayward MWJ, Hartog M. Survey on the use of pulmonary scintigraphy and angiography for suspected pulmonary thromboembolism in the UK. Clin Radio 1991;43:243-5.

17 Gottschalk A, Sostman HD, Coleman RE, et al. Ventilationperfusion scintigraphy in the PIOPED study. II Evaluation of the scintigraphic criteria and interpretations. $7 \mathrm{Nucl} \mathrm{Med}$ 1993;34:1119-26.

18 The PIOPED investigators. Value of the ventilation perfusion scan in acute pulmonary embolism. FAMA 1990;263:2753-9.

19 Cross JJL, Kemp PM, Walsh CG, et al. A randomised trial of spiral CT and ventilation/perfusion scintigraphy for the diagnosis of pulmonary embolism. Clin Radiol 1998;53: 177-82.

20 Van Rossum AB, Treurniet FEE, Kieft GJ, et al. Role of spiral volumetric computed tomographic scanning in the assessment of patients with clinical suspicion of pulmonary embolism and an abnormal ventilation/perfusion lung scan. Thorax 1996;51:23-8.

21 Teigen CL, Maus TP, Sheedy PF, et al. Pulmonary embolism: diagnosis with contrast-enhanced electronbeam CT and comparison with pulmonary angiography. Radiology 1995;194:313-19.

22 Remy-Jardin M, Remy J, Deschildre F, et al. Diagnosis of pulmonary embolism with spiral CT: comparison with pulmonary angiography and scintigraphy. Radiology 1996; pulmonary angi

23 Remy-Jardin M, Remy J, Wattinne L, et al. Central pulmonary thrombo-embolism: diagnosis with spiral volumetric CT with the single breath-hold techniquecomparison with pulmonary angiography. Radiology 1992; 185:381-7

24 Ferretti GR, Bosson J-L, Buttaz P-D, et al. Acute pulmonary embolism: role of helical CT in 164 patients with intermediate probability at ventilation-perfusion scintigraphy and normal results at duplex US of the legs. Radiology 1997;205:453-8.

25 Goodman LR, Curtin JJ, Mewissen MW, et al. Detection of pulmonary embolism in patients with unresolved clinical and scintigraphic diagnosis: helical CT versus angiography. Am fR Roentg 1995;164:1369-74. 